University of Nebraska - Lincoln

DigitalCommons@University of Nebraska - Lincoln

Faculty Publications: Department of

Entomology

Entomology, Department of

1995

\title{
Alfalfa Consumption by Adult Clover Leaf Weevil (Coleoptera: Curculionidae) and Development of Injury Equivalents for Stubble Defoliators
}

\author{
Robert K. D. Peterson \\ DowElanco, Omaha, NE, bpeterson@montana.edu \\ Leon G. Higley \\ University of Nebraska-Lincoln, Ihigley1@unl.edu \\ Stephen D. Danielson \\ University of Nebraska-Lincoln, sdanielson1@unl.edu
}

Follow this and additional works at: https://digitalcommons.unl.edu/entomologyfacpub

Part of the Entomology Commons

Peterson, Robert K. D.; Higley, Leon G.; and Danielson, Stephen D., "Alfalfa Consumption by Adult Clover Leaf Weevil (Coleoptera: Curculionidae) and Development of Injury Equivalents for Stubble Defoliators" (1995). Faculty Publications: Department of Entomology. 280.

https://digitalcommons.unl.edu/entomologyfacpub/280

This Article is brought to you for free and open access by the Entomology, Department of at DigitalCommons@University of Nebraska - Lincoln. It has been accepted for inclusion in Faculty Publications: Department of Entomology by an authorized administrator of DigitalCommons@University of Nebraska - Lincoln. 


\title{
Alfalfa Consumption by Adult Clover Leaf Weevil (Coleoptera: Curculionidae) and Development of Injury Equivalents for Stubble Defoliators
}

\author{
ROBERT K. D. PETERSON, ${ }^{1}$ LEON G. HIGLEY, AND STEPHEN D. DANIELSON \\ Department of Entomology, University of Nebraska-Lincoln, Lincoln, NE 68583-0816
}

\begin{abstract}
J. Econ. Entomol. 88(5): 1441-1444 (1995)
ABSTRACT Experiments were conducted from 1990 through 1992 to determine consumption rates and feeding duration of adult clover leaf weevils, Hypera punctata (F.), to characterize the injury potential of this species during alfalfa regrowth. Adults were fed for $29 \mathrm{~d}$ in 1990 and $18 \mathrm{~d}$ in both 1991 and 1992 . The mean cumulative consumption per adult was 27.2 $\pm 1.6 \mathrm{~cm}^{2}$ and $92.7 \pm 3.5 \mathrm{mg}$ dry weight in 1991 and $24.6 \pm 0.9 \mathrm{~cm}^{2}$ and $87.5 \pm 2.9 \mathrm{mg}$ dry weight in 1992. The mean cumulative consumption pattern was curvilinear for both dry weight and leaf area consumption. Most consumption was within $11 \mathrm{~d}$ of adult eclosion. The peak consumption rate occurred $\approx 5 \mathrm{~d}$ after adult emergence. Because the highest consumption rates and the greatest percentage of defoliation were within the first $11 \mathrm{~d}$ of emergence, adult clover leaf weevils potentially can delay regrowth of alfalfa stubble when adult emergence coincides with the 1st harvest. Further, because adult consumption patterns between clover leaf weevils and alfalfa weevils are similar, alfalfa stubble defoliation thresholds developed for alfalfa weevils and cutworms also can be used for clover leaf weevils. Injury equivalents (injury by 1 species in terms of another species) are determined for adult clover leaf weevils, larval variegated cutworm, Peridroma saucia (Hübner), and larval and adult alfalfa weevils, Hypera postica (Gyllenhal).
\end{abstract}

KEY WORDS Hypera punctata, injury guild, pest management

THE Clover LEAF weevil, Hypera punctata (F.) was accidentally introduced into New York in $\approx 1880$. The species now occurs throughout most of the United States and southern Canada where alfalfa, Medicago sativa L., and clover, Trifolium spp., are present.

Typically, partially grown larvae overwinter in or near alfalfa or clover crowns. However, in some areas, eggs, larvae, and adults may overwinter. Larvae become active in early spring and feed on leaves in the lower portion of the plant canopy. From late April to mid-May, larvae pupate within organic debris on the soil surface. Adults emerge within $2 \mathrm{wk}$ and feed for $3-4 \mathrm{wk}$ on clover, alfalfa, and occasionally soybean leaf tissue (Peterson 1994) before aestivating for much of the late spring and summer. Both larvae and adults injure leaves by feeding on the interveinal tissue. The defoliation injury is similar in appearance to alfalfa weevil, Hypera postica (Gyllenhal), feeding. Adults become active in the fall to mate and oviposit. In most locations, there is only 1 generation per year.

The clover leaf weevil was a serious alfalfa pest in eastern Nebraska in 1989, 1990, and 1991. Those outbreaks occurred after mild winters that were followed by dry springs. Indeed, historical cli-

'DowElanco, 9802 Nicholas, Suite 350, Omaha, NE 68114. mate data (Meyer et al. 1994) indicate that 1989 had the lowest recorded precipitation totals $<17.8$ $\mathrm{cm}$ ) from 1 March through 30 June throughout eastern Nebraska. Precipitation totals for the same period in 1988 were the 6th lowest on record $(<22.9 \mathrm{~cm})$. Normal precipitation during this period is $38 \mathrm{~cm}$. Low precipitation totals most likely contributed to lower larval mortality from the fungus Entomophthora sphaerosperma (Metcalf et al. 1962).

Most clover leaf weevil damage is caused by large larval populations during the 1st spring growth period (Metcalf et al. 1962). However, in eastern Nebraska, injury by larvae and adults after the 1st growth has been more serious (especially in 1989 and 1990). Alfalfa consumption by clover leaf weevil adults immediately after the lst harvest significantly delayed regrowth, causing phenological delays. Indeed, many growers lost a complete harvest in heavily infested fields because of maturation delays (Anonymous 1989).

We conducted studies from 1990 through 1992 to determine consumption rates and feeding duration of adult clover leaf weevils to characterize the injury potential of this species during alfalfa regrowth. This information can be used to help establish appropriate economic injury levels. 

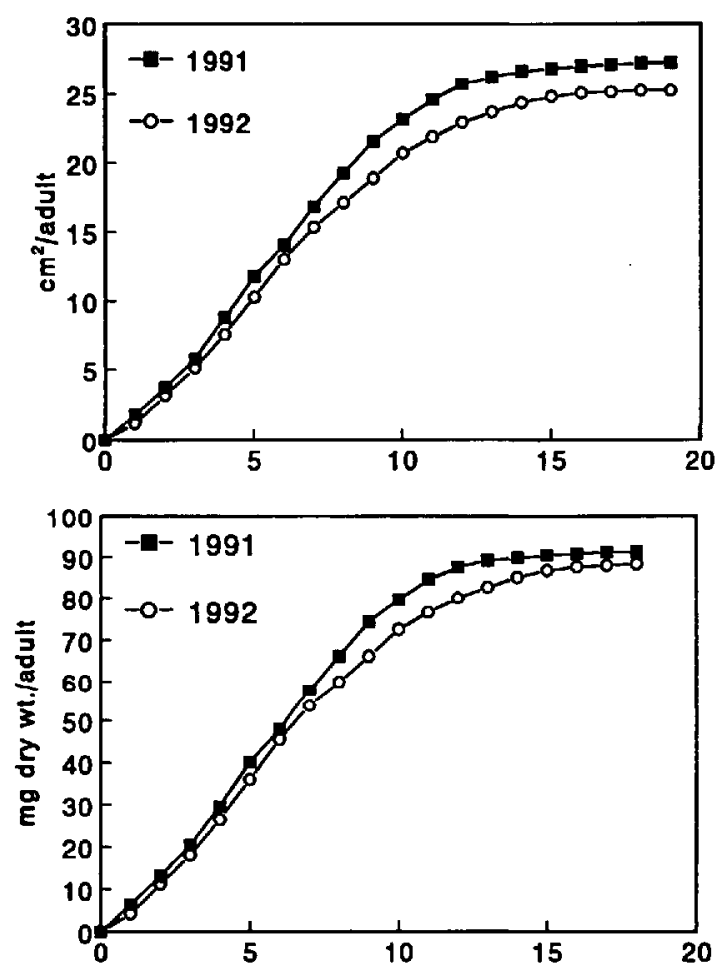

Days After Adult Emergence

Fig. 1. Mean cumulative consumption of alfalfa by clover leaf weevil adults.

\section{Materials and Methods}

Fourth-instar and pupal clover leaf weevils were collected from alfalfa fields and held until eclosion. Into each $8.5-\mathrm{cm}$-diameter plastic dish, 4 newly emerged adults in 1990 and 2 adults in 1991 and 1992 were placed with 2 filter papers, and maintained at $\approx 75 \% \mathrm{RH}$. Filter papers were moistened with distilled water. Plastic dishes were placed randomly in an environment chamber $\left(23^{\circ} \mathrm{C}\right.$, photoperiod of 14:10 [L:D] h). Thirteen dishes (52 adults) in 1990, 9 dishes ( 18 adults) in 1991, and 27 dishes (54 adults) in 1992 were used to calculate consumption rates.

Each adult was provided with at least 1 fieldcollected alfalfa leaflet ('Haymaker') every 24-48 h. Areas (square centimeters) were measured for each leaflet before consumption using an area meter (LI-COR, Model 3100, Lincoln, NE). Every 24 $h$, leaflets were removed from the dishes and areas were measured. Then, leaflets were either replaced or returned to the dishes.

Total leaf tissue consumption and consumption rates per day for each adult were determined until feeding ceased. Specific leaf weights were quantified by determining the ratios between leaf area and dry weight (milligrams of dry weight per square centimeter) of remaining tissue. We also at-
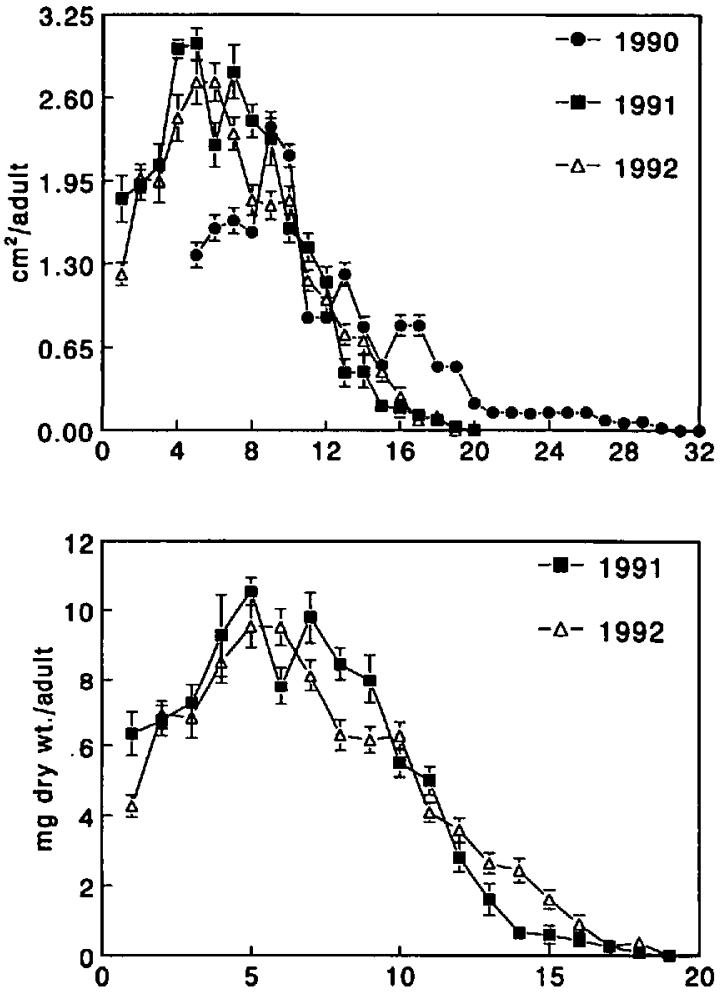

Days After Adult Emergence

Fig. 2. Mean consumption of alfalfa per day for clover leaf weevil adults. Capped lines are standard error.

tempted to determine consumption rates for clover leaf weevil larvae. However, the larvae were very susceptible to fungal diseases and could not be kept alive.

\section{Results and Discussion}

Adults fed for $29 \mathrm{~d}$ in 1990 and $18 \mathrm{~d}$ in both 1991 and 1992. The mean cumulative consumption per adult was $27.2 \pm 1.6 \mathrm{~cm}^{2}$ and $92.7 \pm 3.5 \mathrm{mg}$ dry weight in 1991 and $24.6 \pm 0.9 \mathrm{~cm}^{2}$ and 87.5 $\pm 2.9 \mathrm{mg}$ dry weight in 1992. Consumption data were not available for the first $4 \mathrm{~d}$ of the experiment in 1990 because the beetles consumed all of the leaf tissue that was provided. The mean cumulative consumption pattern was curvilinear for both dry weight and leaf area consumption (Fig. 1). Little leaf tissue was consumed after $\approx 14 \mathrm{~d}$. The majority of consumption was within $11 \mathrm{~d}$ of adult eclosion in 1990 (Figs. 1 and 2). Similarly, adults consumed $90 \%$ of leaf tissue within $11 \mathrm{~d}$ of eclosion in 1991 and 1992 (Figs. 1 and 2). Fifty percent of alfalfa consumption was within $6 \mathrm{~d}$ of adult emergence in all experiments. The peak consumption rate occurred $5 \mathrm{~d}$ after adult emergence in 1991 and 5 and $6 \mathrm{~d}$ after emergence in 1992 (Fig. 2). 
Adult clover leaf weevil consumption patterns were similar to previously reported feeding patterns for adult alfalfa weevils (Koehler and Gyrisco 1963, Barnes and Ratcliffe 1967, Bjork and Davis 1984). Both species consumed the most leaf tissue within $\approx 11 \mathrm{~d}$ of emergence. Maximum consumption per day for both species occurred on $\approx 5$ th $d$ following adult emergence.

Durations of consumption, however, are most likely different between the 2 species. In this study, adult clover leaf weevils fed from 18 to $29 \mathrm{~d}$. Previous studies using environment chambers maintained at $20-21^{\circ} \mathrm{C}$ indicate that the duration of adult alfalfa weevil consumption ranged from 32 to $50 \mathrm{~d}$, although $>80 \%$ of tissue was consumed within the first $20 \mathrm{~d}$ after adult emergence (Koehler and Gyrisco 1963, Barnes and Ratcliffe 1967). In a study using field cages, Bjork and Davis (1984) determined that consumption continued for $37 \mathrm{~d}$ after adult emergence. As with previous environment chamber studies, nearly all tissue was consumed within $20 \mathrm{~d}$ of adult emergence.

In 1990, clover leaf weevil adults may have fed for $10 \mathrm{~d}$ longer than adults in 1991 and 1992, becamse they did not feed to satiation during the first $4 \mathrm{~d}$ or there were 4 adults instead of 2 in each dish. Crowding may have reduced feeding rates and extended feeding duration.

Alf:alfa stubble defoliators, such as alfalfa weevil adults and cutworms, consume dry matter, delay regrowth initiation and subsequent plant maturity, and reduce growth rates after defoliation (Hutchins et al. 1990). The reduction in alfalfa vigor also encourages weed encroachment which may reduce forage: quality and stand longevity (Berberet et al. 1987, Buntin 1989). Because the highest consumption rates and the greatest percentage of defoliation were within the first $11 \mathrm{~d}$ of emergence, adult clover leaf weevils potentially can delay regrowth of alfalfa stubble when adult emergence coincides with the lst harvest.

There is no evidence to suggest that stubble injury by clover leaf weevils produces plant responses different from alfalfa weevil or cutworm injury. Clover leaf weevil feeding is a form of gross tissue removal (Pedigo et al. 1986), as is injury by alfalfa weevil and cutworm species. Previous research on gross tissue removal in alfalfa by alfalfa weevil showed that gross tissue removal produced no reductions in photosynthetic rates of remaining tissue (Peterson et al. 1992).

Hutchins et al. (1988), Hutchins and Funderburk (1991), and Higley et al. (1993) detail requirements for establishing injury guilds based on homogeneity in physiological response to injury. Pest species must (1) produce a similar type of injury, (2) produce injury within the same phenological time frame of the host, (3) produce injury of a similar intensity, and (4) affect the same plant part (Hutchins and Funderburk 1991). Consumption patterns and timing of injury are similar for adult clover leaf weevil and adult alfalfa weevil. Also,
Table 1. Injury equivalents for the alfalfa leaf-fending guild (based on consumption rate differences)

\begin{tabular}{lllcc}
\hline \hline \multirow{2}{*}{ Equivalency basis } & \multicolumn{4}{c}{ Insect equivalents } \\
\cline { 2 - 5 } & $\begin{array}{c}\text { Alfalfa } \\
\text { weevil } \\
\text { adult }\end{array}$ & $\begin{array}{c}\text { Alfalfa } \\
\text { weevil } \\
\text { larva }\end{array}$ & $\begin{array}{c}\text { Clover } \\
\text { leaf } \\
\text { weevil } \\
\text { adlult }\end{array}$ & $\begin{array}{c}\text { Vario- } \\
\text { gated } \\
\text { cut- } \\
\text { worm } \\
\text { larva }\end{array}$ \\
\hline Alfalfa weevil adult & 1 & 0.67 & 4 & 20 \\
Alfalfa weevil larva & 3 & 1 & 12 & 60 \\
Variegated cutworm larva & 0.05 & 0.02 & 0.2 & 1 \\
Clover leaf weevil adult & 0.25 & 0.08 & 1 & 5 \\
\hline
\end{tabular}

both species produce the same type of injury, gross tissue removal. Consequently, the species seem to meet the requirements for representing a common injury guild on alfalfa. Cutworm leaf feeding on alfalfa also could be represented in this guild.

Our results indicate that individual clover leaf weevil adults consume $\approx 4$ times the leaf tissue that alfalfa weevil adults consume (Bjork and Davis 1984) and one-fifth times the leaf tissue that variegated cutworm larvae, Peridroma saucia (Hübner), consume (Buntin and Pedigo 1985b). Therefore, these differences need to be considered when assessing potential damage and calculating defoliation thresholds. Practically, recognizing a common injury guild allows for multiple-species management and the use of common guidelines for many species (Hutchins et al. 1988, Hutchins and Funderburk 1991). Alfalfa stubble defoliation thresholds developed by Buntin and Pedigo (1985a) and those used in management recommendations for alfalfa weevils and cutworms could be modified for use with clover leaf weevils.

It is possible to calculate the injury equivalency, a representation of injury by 1 species in terms of another (Hutchins et al. 1988), for this guild of alfalfa defoliators (Table 1). This allows the use of alfalfa weevil or cutworm economic thresholds for clover leaf weevil, as well as the use of these thresholds for 2 or more species should they cooccur in a field.

For example, a threshold of 10 alfalfa weevil adults would produce a threshold of 2.5 adult clover leaf weevils (10/4) or 0.5 variegated cutworms (10/20) based on injury equivalents. Similarly, a mixed population of 10 alfalfa weevils and 6 clover leaf weevils would be equivalent to a population of 34 alfalfa weevils $(10 \times 1+6 \times 4)$ (see Hutchins et al. [1988] for more detail on injury equivalency).

It seems likely that other species, such as clover root curculio adults, Sitona hispidula (F.), conld be added to this guild once information on consumption rates is determined. Also, consumption rates for clover leaf weevil larvae need to be determined because they can co-occur with adults in alfalfa stubble. 


\section{Acknowledgments}

We thank F. Baxendale, S. Spomer, and J. Witkowski (University of Nebraska) for reviewing the manuscript. We also thank M. Peterson, A. Guerra, K. Jarvi, R. Seymour, S. Spomer, and B. Vlach for technical assistance. This is paper 11026 of the journal series of the Agricultural Research Division, University of Nebraska-Lincoln. This research was supported by University of Nebraska Agricultural Experiment Station Projects 17-047, 17-048, and 17-059.

\section{References Cited}

Anonymous. 1989. Crop-pest update. Insect, plant disease, and weed science news. Coop. Ext. Univ. Nebr. Lincoln. 89(13): 1 .

Barnes, D. K. and R. H. Ratcliffe. 1967. Leaf disk method of testing alfalfa plants for resistance to feeding by adult alfalfa weevils. J. Econ. Entomol. 60: 1561-1565.

Berberet, R. C., J. F. Stritzke, and A. K. Dowdy. 1987. Interactions of alfalfa weevil (Coleoptera: Curculionidae) and weeds in reducing yield and stand of alfalfa. J. Econ. Entomol, 80: 1306-1313.

Bjork, C. D. and D. W. Davis. 1984. Consumption of alfalfa by adult alfalfa weevils (Coleoptera: Curculionidae). Environ. Entomol. 13: 432-438.

Buntin, G. D. 1989 . Competitive interactions of alfalfa and annual weeds as affected by alfalfa weevil (Coleoptera: Curculionidae) stubble defoliation. J. Entomol. Sci. 24: 78-83.

Buntin, G. D. and L. P. Pedigo. 1985a. Development of economic injury levels for last-stage variegated cutworm (Lepidoptera: Noctuidae) larvae in alfalfa stubble. J. Econ. Entomol. 78: 1341-1346.

1985b. Variegated cutworm (Lepidoptera: Noctuidae) foliage consumption and larval development on alfalfa. J. Econ. Entomol. 78: 482-484.

Higley, L. G., J. A. Browde, and P. M. Higley. 1993. Moving towards new understandings of biotic stress and stress interactions. International Crop Science I. Crop Science Soc. Am., Madison, WI.

Hutchins, S. H. and J. E. Funderburk. 1991. Injury guilds: a practical approach for managing pest losses to soybean. Agric. Zool. Rev. 4: 1-21.

Hutchins, S. H., G. D. Buntin, and L. P. Pedigo. 1990. Impact of insect feeding on alfalfa regrowth: a review of physiological responses and economic consequences. Agron. J. 82: 1035-1044.

Hutchins, S. H., L. G. Higley, and L. P. Pedigo. 1988. Injury equivalency as a basis for developing multiple-species economic injury levels. J. Econ. Entomol. 81: $1-8$.

Koehler, C. S. and G. G. Gyrisco. 1963. Studies on the feeding behavior of alfalfa weevils from the eastern and western United States. J. Econ. Entomol, 56: $489-492$.

Metcalf, C. L., W. P. Flint, and R. L. Metcalf. 1962. Destructive and useful insects: their habits and control. 4th ed. McGraw-Hill, New York.

Meyer, S. J., S. A. Ameri, and K. G. Hubbard. 1994. User's guide: ClimProb 3.1-software for assisting climate-related decision making. High Plains Climate Center, Report 94-5. University of Nebraska-Lincoln, Lincoln.

Pedigo, L. P., S. H. Hutchins, and L. G. Higley. 1986. Economic injury levels in theory and practice. Annu. Rev. Entomol. 31: 341-368.

Peterson, R.K.D. 1994. Clover leaf weevil, pp. 46-47. In L. G. Higley and D. J. Boethel [eds.], Handbook of soybean insect pests. Entomological Society of America, Lanham, MD.

Peterson, R.K.D., S. D. Danielson, and L. G. Higley. 1992. Photosynthetic responses of alfalfa to actual and simulated alfalfa weevil (Coleoptera: Curculionidae) injury. Environ. Entomol. 21: 501-507.

Received for publication 24 February 1995; accepted 10 April 1995. 